\title{
Supplementation of vitamin $E$ and selenium in different diets on performance of IPB D-2 chicken during developer-layer period
}

\author{
Beby Murba Ningsih Saragih ${ }^{1}$, Sumiati Sumiati, ${ }^{2, *}$, and Rita Mutia ${ }^{2}$ \\ ${ }^{1}$ Student of Department of Nutrition and Feed Technology, Faculty of Animal Science, IPB \\ University, Bogor 16680, Indonesia. \\ ${ }^{2}$ Department of Nutrition and Feed Technology, Faculty of Animal Science, IPB University, Bogor \\ 16680, Indonesia
}

\begin{abstract}
Supplementation of vitamin E and selenium improved the productivity of livestock. This study aims to evaluate the effect of vitamin $\mathrm{E}$ and selenium supplementation on different diets of IPB D-2 chickens during 15-21 weeks. Completely randomized factorial 2 × 2 (factor A was diet type and factor B was vitamin E supplementation) and five replications was used in this experiment. The variables observed were performance, blood profile, organ immunity and percentage of carcass weight. The results showed that diet type had a significant effect $(\mathrm{P}<0.05)$ on feed consumption in the developer and layer periods and had a highly significant effect $(\mathrm{P}<0.01)$ on feed consumption in the pre-layer period and body weight gain in the layer period. Vitamin $\mathrm{E}$ and selenium supplementation had a significant effect $(\mathrm{P}>0.05)$ on pre-layer feed consumption. The blood profile was in normal range with optimal stress levels. There was significantly interaction $(\mathrm{P}<0.05)$ between diet type and vitamin $\mathrm{E}$ supplementation on carcass percentage and highly significantly interaction $(\mathrm{P}<0.01)$ on layer feed conversion. Parameters of immune organ and egg production were not affected by treatment. The diet type was reduced by $5 \%$ from the standard with supplementation vitamin $\mathrm{E}$ dan selenium showed the best result for IPB D-2 chicken performance.
\end{abstract}

\section{Introduction}

Poultry products, especially native chickens, make a significant contribution to meeting the food and nutritional needs of the community. Consumers prefer the taste of free-range chicken meat and eggs. The increase in consumption of native chicken meat and eggs is not balanced with their availability because the development of domestic chicken itself is still relatively low. In addition to the low development, domestic chickens themselves have a slow growth rate. Efforts have been made to overcome this problem by crossing. One of the crossbreed chickens that have almost the same taste as native chicken is IPB D-1 chicken.

IPB D-1 chickens result from a cross from three chicken families, Pelung chickens, native chickens, and Sentul chickens with broilers. IPB D-1 chickens were divided into two

\footnotetext{
*Corresponding author: y_sumiati@yahoo.com
} 
lines, male candidate line (IPB D-3) and female line candidate (IPB D-2). IPB D-2 chickens are genetically the same as IPB D-1 chickens. IPB D-2 chickens are prospective female strains (female) that have been selected with an IgY indicator of at least $10 \mathrm{mg} / \mathrm{ml}$ blood, body weight at 12 weeks of age $1.3 \mathrm{~kg}$ for males, and $1.1 \mathrm{~kg}$ for females. The purpose of establishing this IPB chicken is to increase the participation of local chickens, which have advantages in the form of meat taste and resistance to disease and can utilize local feed but have a weakness in the form of slow growth [1].

Chicken growth is influenced by feed quality and environmental factors. IPB's chicken performance and productivity can be improved by the quality and quantity of feed provided. Quality feed must contain the nutrients needed according to age development and maintenance purposes. The provision of the local chicken feed itself is still based on various sources, including the recommendation of Scott et al. (1982), NRC (1994), and Lesson and Summers (2005). The standard is actually for broilers, while the standard for local chickens' energy metabolism and protein requirements does not yet exist.

Another thing that can be done to increase the productivity of IPB chickens is to do vitamin and mineral supplementation. Vitamin and mineral supplementation play an essential role for livestock even though they are needed in small amounts. Lack of vitamins and minerals will have an impact on the growth of livestock production. One of the vitamins and minerals that can synergize well is vitamin $\mathrm{E}$ and selenium. So, this synergistic combination can act and protect tissues against oxidative damage and enhance the immune response [2]. Based on the description above, it is necessary to conduct research that discusses the effect of vitamin $\mathrm{E}$ and selenium supplementation on different diet to increase the performance and productivity of IPB D-2 chickens.

\section{Materials and methods}

\subsection{Research time}

This research was from February 2021 to April 2021. Raising IPB D-2 Chicken was carried out at the Poultry Animal Nutrition Field Laboratory. The analysis was carried out at the Poultry Livestock Nutrition Laboratory and the Meat and Work Livestock Laboratory, Faculty of Animal Husbandry, Bogor Agricultural University.

\subsubsection{Tools and materials}

The tools used in this study include battery cages, Thermo hygrometers, digital scales, feed and drink containers, lights, and fans. The materials used in this study were 80 IPB D-2 chickens aged 15 weeks, vitastress, disinfectant, rice husk, and limestone. Chickens were divided into four treatments consisting of 5 replications with a total of 20 experimental units, and each replication consisted of 4 chickens.

\subsubsection{Work procedures}

Before use, the cage was sanitized first by liming the floor and walls of the cage. After sanitation, the cage was left for a week before being used for maintenance. Then the equipment for feeding and drinking water were washed by using detergent. Then, the research ration formulation was prepared based on the nutritional needs of Lesson and Summers [3]. The treatment ratio consisted of R1S1, which was the standard ratio of Lesson and Summers [3] without supplementation, R1S2 was the standard ratio of Lesson and Summers [3] + Vitamin E (100 ppm) and Selenium (1 ppm), R2S1 was the ratio that 
was reduced by $5 \%$ of energy requirements, and the protein was from the R1S1 ration, and R2S2 was the R2S1 + vitamin E (100 ppm) and selenium (1 ppm) rations. The ingredients used in the formulation and composition of feed ingredients are shown in Table 1.

Table 1. Composition and nutrients content of dietary treatments.

\begin{tabular}{|c|c|c|c|c|c|c|}
\hline \multirow{3}{*}{$\begin{array}{l}\text { Feed } \\
\text { Ingredients } \\
(\%)\end{array}$} & \multicolumn{6}{|c|}{ Treatment ration } \\
\hline & \multicolumn{3}{|c|}{$\mathbf{R} 1$} & \multicolumn{3}{|c|}{$\mathbf{R 2}$} \\
\hline & Developer & $\begin{array}{l}\text { Pre- } \\
\text { layer }\end{array}$ & Layer & Developer & $\begin{array}{l}\text { Pre- } \\
\text { layer }\end{array}$ & Layer \\
\hline Yellow corn & 55.00 & 60.00 & 53.56 & 44.50 & 48.45 & 49.20 \\
\hline Rice bran & 22.55 & 13.00 & 0.00 & 37.75 & 30.00 & 11.00 \\
\hline Soybean meal & 15.00 & 10.00 & 22.05 & 10.00 & 10.50 & 19.00 \\
\hline Meat Bone Meal & 2.00 & 9.00 & 9.90 & 3.00 & 3.50 & 7.58 \\
\hline Palm oil & 2.00 & 2.00 & 4.50 & 1.00 & 1.00 & 2.60 \\
\hline DCP & 0.65 & 1.00 & 1.98 & 0.65 & 0.93 & 1.65 \\
\hline $\mathrm{CaCO} 3$ & 1.80 & 4.00 & 7.65 & 1.80 & 4.50 & 8.40 \\
\hline $\mathrm{Nacl}$ & 0.20 & 0.20 & 0.16 & 0.20 & 0.20 & 0.25 \\
\hline Premix & 0.50 & 0.50 & 0.01 & 0.50 & 0.50 & 0.01 \\
\hline L-Lysine & 0.10 & 0.12 & 0.00 & 0.30 & 0.17 & 0.01 \\
\hline DL-Methionine & 0.20 & 0.18 & 0.19 & 0.30 & 0.25 & 0.30 \\
\hline Total & 100.00 & 100.00 & 100.00 & 100.00 & 100.00 & 100.00 \\
\hline
\end{tabular}

R1: Standard diet Lesson and Summers [3], R2: diet which energy metabolizable energy and protein content 5\% below the standard, Developer (15-17 weeks), Pre-layer (17-19 weeks), Layer (19-21 weeks)

\subsubsection{Maintenance}

IPB D-2 chickens aged 15 weeks were placed in a battery cage and raised for six weeks, with feeding done two times a day, 50\% in the morning and 50\% in the afternoon. While the provision of drinking water ad libitum. Feed consumption data was measured every day, and body weight gain was carried out every week. Disease control is done by regularly replacing the husks when they are wet.

\subsubsection{Observed variables}

The variables observed in this study: performances (feed consumption, body weight gain, FCR, and egg production), percentage of immune organ weight, blood profile, and percentage of carcass weight. 


\subsubsection{Data analysis and experimental design}

Completely randomized factorial $2 \times 2$ pattern with factor A was the diets type including R1: Standard diet [3] and R2: $<5 \%$ Standard diet [3]. Factor B was S1: Without supplementation of vitamin E and Selenium and S2: Supplementation of vitamin E (100 $\mathrm{ppm})$ and selenium $(1 \mathrm{ppm})$ with five replications. Analysis data used analysis of variance (ANOVA). If the analysis shows a significantly different effect, it is continued using the Duncan multiple range test.

\section{Results and discussion}

\subsection{IPB D-2 chicken performance developer period}

Data on the performance of IPB D-2 chickens during the developer period are presented in Table 3. There was no interaction between diet type and vitamin $\mathrm{E}$ and selenium supplementation on performance IPB D-2 chickens at developer period. The diet type for IPB D-2 chickens had a significant effect $(\mathrm{P}<0.05)$ on feed consumption. The diet which energy metabolizable energy and protein content $5 \%$ below the standard resulted higher feed consumption. The occurrence of differences in feed consumption in this study was caused by differences in metabolizable energy and protein between R1 and R2. The high consumption indicated that the ME and protein contents did not meet the needs of IPB D-2 chickens. Rasyaf [4] stated that energy requirements and ration energy levels influence ration consumption. If the energy level can meet the needs of life, the ration consumed is less and vice versa.

Table 3. The performance of IPB D-2 chicken during the developer (15-17 weeks) period with different diet type and vitamin $\mathrm{E}$ and selenium supplementation.

\begin{tabular}{|c|c|c|c|c|}
\hline \multirow{2}{*}{ Parameters } & \multirow{2}{*}{$\begin{array}{l}\text { Supplementation } \\
\text { Vit. E dan Se }\end{array}$} & \multicolumn{2}{|c|}{ Treatment } & \multirow{2}{*}{ Mean } \\
\hline & & R1 & $\mathbf{R} 2$ & \\
\hline \multirow{4}{*}{$\begin{array}{l}\text { Feed } \\
\text { consumption } \\
\text { (g/bird/day) }\end{array}$} & $\mathrm{S} 1$ & $87.29 \pm 1.40$ & $91.60 \pm 2.08$ & $89.69 \pm 2.80$ \\
\hline & S2 & $90.03 \pm 5.31$ & $93.13 \pm 0.91$ & $91.58 \pm 4.11$ \\
\hline & Mean & $88.81 \pm 4.29^{b}$ & $92.36 \pm 1.77^{\mathrm{a}}$ & \\
\hline & P-Value & \multicolumn{2}{|c|}{0.033} & \\
\hline \multirow{4}{*}{ BWG (g/bird) } & S1 & $98.85 \pm 21.08$ & $92.47 \pm 15.80$ & $96.01 \pm 19.18$ \\
\hline & $\mathrm{S} 2$ & $110.28 \pm 18.67$ & $90.30 \pm 14.39$ & $100.29 \pm 19.43$ \\
\hline & Mean & $104.56 \pm 20.72$ & $91.26 \pm 15.07$ & \\
\hline & P-Value & \multicolumn{2}{|c|}{0.173} & \\
\hline \multirow{3}{*}{ FCR } & S1 & $6.32 \pm 0.81$ & $7.51 \pm 0.88$ & $6.85 \pm 1.03$ \\
\hline & $\mathrm{S} 2$ & $6.08 \pm 0.96$ & $7.91 \pm 2.04$ & $7.00 \pm 1.84$ \\
\hline & Mean & $6.20 \pm 0.90^{\mathrm{a}}$ & $7.74 \pm 1.64^{b}$ & \\
\hline
\end{tabular}




\begin{tabular}{|l|l|c|c|}
\hline & P-Value & 0.039 & \\
\hline
\end{tabular}

S1: Without vitamin E and Se supplementation, S2: vitamin E supplementation (100 ppm) and Se (1 ppm), R1: Standard ration Lesson and Summers [3], R2: R1 <5\% of energy metabolism and protein requirements

The results in Table 3 showed that the diet type and vitamin $\mathrm{E}$ and selenium supplementation in IPB D-2 chickens had no significant effect $(\mathrm{P}>0.05)$ on body weight gain. The ration conversion was significantly affected $(\mathrm{P}<0.05)$ by the diet type. The conversion of the ration with the diet which metabolizable energy and protein content $5 \%$ below the standard (R2), was more significant than the standard ration (R1). The difference in the value of the ration conversion between the $\mathrm{R} 2$ and $\mathrm{R} 1$ diet type was caused by the consumption of more rations and due to relatively lower bodyweight gain. The resulting ration conversion was more incredible.

Table 4. The performance of IPB D-2 chicken during the pre-layer (17-19 weeks) period with different diet type and vitamin $\mathrm{E}$ and selenium supplementation.

\begin{tabular}{|c|c|c|c|c|c|}
\hline \multirow{2}{*}{ Parameters } & \multirow{2}{*}{$\begin{array}{l}\text { Supplementation } \\
\text { Vit. E dan Se }\end{array}$} & \multicolumn{2}{|c|}{ Treatment } & \multirow{2}{*}{ Mean } & \multirow{2}{*}{$\begin{array}{c}\text { P- } \\
\text { Value }\end{array}$} \\
\hline & & $\mathbf{R} 1$ & $\mathbf{R 2}$ & & \\
\hline \multirow{4}{*}{$\begin{array}{l}\text { Feed } \\
\text { consumption } \\
\text { (g/bird/day) }\end{array}$} & $\mathrm{S} 1$ & $90.59 \pm 0.62$ & $96.45 \pm 3.82$ & $93.19 \pm 3.90^{\mathrm{b}}$ & \multirow{3}{*}{0.004} \\
\hline & $\mathrm{S} 2$ & $95.12 \pm 2.49$ & $99.56 \pm 0.28$ & $97.34 \pm 2.84^{\mathrm{a}}$ & \\
\hline & Mean & $92.85 \pm 2.90^{\mathrm{b}}$ & $98.18 \pm 2.99^{\mathrm{a}}$ & & \\
\hline & P-Value & \multicolumn{2}{|c|}{0.0004} & & 0.543 \\
\hline \multirow{4}{*}{$\begin{array}{l}\text { BWG } \\
\text { (g/bird) }\end{array}$} & $\mathrm{S} 1$ & $80.66 \pm 5.62$ & $80.21 \pm 7.26$ & $80.46 \pm 6.40$ & \multirow{3}{*}{0.832} \\
\hline & $\mathrm{S} 2$ & $85.89 \pm 15.19$ & $77.00 \pm 3.65$ & $80.95 \pm 11.38$ & \\
\hline & Mean & $82.89 \pm 11.26$ & $78.43 \pm 5.77$ & & \\
\hline & P-Value & \multicolumn{2}{|c|}{0.335} & & 0.382 \\
\hline \multirow{4}{*}{ FCR } & $\mathrm{S} 1$ & $8.04 \pm 0.77$ & $8.72 \pm 1.49$ & $8.43 \pm 1.20$ & \multirow{3}{*}{0.888} \\
\hline & S2 & $7.85 \pm 2.05$ & $9.10 \pm 0.46$ & $8.48 \pm 1.61$ & \\
\hline & Mean & $7.95 \pm 1.55$ & $8.93 \pm 1.07$ & & \\
\hline & P-Value & \multicolumn{2}{|c|}{0.184} & & 0.692 \\
\hline
\end{tabular}

S1: Without vitamin E and Se supplementation, S2: vitamin E supplementation (100 ppm) and Se (1 ppm), R1: Standard ration Lesson and Summers [3], R2: R1 <5\% metabolism energy and protein requirements

Data on the performance of IPB D-2 chickens during the pre-layer period are presented in Table 4. There was no interaction between diet type and vitamin $\mathrm{E}$ and selenium supplementation on performance IPB D-2 chickens pre-layer period. The diet type with vitamin $\mathrm{E}$ and selenium supplementation had a significant effect $(\mathrm{P}<0.05)$ on feed consumption in the pre-layer period of IPB D-2 chickens. The high feed consumption of 
IPB D-2 chickens with the diet of metabolizable energy and protein content $5 \%$ below the standard indicated that the R2 diet type was not meeting the needs. The IPB D-2 chickens consumed more rations than the standard R1 diet type.

Table 5. The performance of IPB D-2 chicken during the layer (19-21 weeks) period with different diet type and vitamin $\mathrm{E}$ and selenium supplementation.

\begin{tabular}{|c|c|c|c|c|c|}
\hline \multirow{2}{*}{ Parameters } & \multirow{2}{*}{$\begin{array}{l}\text { Supplementatio } \\
\text { n Vit. E dan Se }\end{array}$} & \multicolumn{2}{|c|}{ Treatment } & \multirow{2}{*}{ Mean } & \multirow{2}{*}{$\begin{array}{l}\text { P- } \\
\text { Value }\end{array}$} \\
\hline & & R1 & $\mathbf{R 2}$ & & \\
\hline \multirow{4}{*}{$\begin{array}{l}\text { Feed } \\
\text { consumption } \\
\text { (g/bird) }\end{array}$} & $\mathrm{S} 1$ & $101.15 \pm 0.94$ & $107.41 \pm 7.19$ & $104.28 \pm 6.01$ & \multirow{3}{*}{0.389} \\
\hline & $\mathrm{S} 2$ & $103.62 \pm 3.85$ & $108.58 \pm 0.15$ & $106.10 \pm 3.68$ & \\
\hline & Mean & $102.39 \pm 3.06^{\mathrm{b}}$ & $107.99 \pm 5.12^{\mathrm{a}}$ & & \\
\hline & P-Value & \multicolumn{2}{|c|}{0.015} & & 0.753 \\
\hline \multirow{4}{*}{$\begin{array}{l}\text { BWG } \\
\text { (g/bird) }\end{array}$} & $\mathrm{S} 1$ & $88.39 \pm 3.22$ & $80.43 \pm 7.74$ & $84.41 \pm 7.14^{b}$ & \multirow{3}{*}{0.012} \\
\hline & $\mathrm{S} 2$ & $100.04 \pm 3.89$ & $83.88 \pm 5.23$ & $91.96 \pm 9.30^{\mathrm{a}}$ & \\
\hline & Mean & $94.22 \pm 6.83^{\mathrm{a}}$ & $82.15 \pm 6.82^{b}$ & & \\
\hline & P-Value & \multicolumn{2}{|c|}{0.0003} & & 0.142 \\
\hline \multirow{4}{*}{ FCR } & $\mathrm{S} 1$ & $8.03 \pm 0.27^{\mathrm{b}}$ & $5.42 \pm 0.26^{\mathrm{a}}$ & $8.74 \pm 0.90^{\mathrm{b}}$ & \multirow{3}{*}{0.0002} \\
\hline & S2 & $5.42 \pm 0.26^{\mathrm{a}}$ & $9.13 \pm 0.58^{\mathrm{c}}$ & $7.28 \pm 1.91^{\mathrm{a}}$ & \\
\hline & Mean & $6.72 \pm 1.33^{\mathrm{a}}$ & $9.29 \pm 0.68^{b}$ & & \\
\hline & P-Value & \multicolumn{2}{|c|}{0.0002} & & 0.0003 \\
\hline
\end{tabular}

S1: Without vitamin E and Se supplementation, S2: vitamin E supplementation (100 ppm) and Se (1 ppm), R1: Standard ration Lesson and Summers [3], R2: R1 <5\% metabolic energy and protein requirements

Data on the performance of IPB D-2 chickens during the layer period are presented in Table 5. There was no interaction between diet type and vitamin $\mathrm{E}$ and selenium supplementation on performance IPB D-2 chickens at layer period. The diet type for IPB D2 chickens had a significant effect $(\mathrm{P}<0.05)$ on ration consumption. The increase in body weight of IPB D-2 chickens during the layer period was significantly affected $(\mathrm{P}<0.01)$ by diet type and vitamin $\mathrm{E}$ and selenium supplementation. As for feed conversion, there was a very significant interaction $(\mathrm{P}<0.01)$ between different ratio treatments with vitamin $\mathrm{E}$ and selenium supplementation.

\subsection{Percentage of immune organ weights}

Table 6. Percentage of immune organ weights of IPB D-2 chickens with different diet type and vitamin $\mathrm{E}$ and selenium supplementation

\begin{tabular}{|l|l|c|c|l|}
\hline Parameters & Supplementation & Treatment & Mean & P-Value \\
\hline
\end{tabular}




\begin{tabular}{|c|c|c|c|c|c|}
\hline & Vit. E dan Se & R1 & $\mathbf{R 2}$ & & \\
\hline \multirow{4}{*}{ Spleen } & S1 & $0.38 \pm 0.12$ & $0.35 \pm 0.15$ & $0.37 \pm 0.13$ & \multirow{3}{*}{0.982} \\
\hline & S2 & $0.38 \pm 0.13$ & $0.35 \pm 0.11$ & $0.37 \pm 0.12$ & \\
\hline & Mean & $0.38 \pm 0.13$ & $0.35 \pm 0.13$ & & \\
\hline & P-Value & \multicolumn{2}{|c|}{0.717} & & 0.994 \\
\hline \multirow{4}{*}{ Thymus } & S1 & $0.31 \pm 0.09$ & $0.32 \pm 0.10$ & $0.32 \pm 0.10$ & \multirow{3}{*}{0.07} \\
\hline & S2 & $0.23 \pm 0.05$ & $0.22 \pm 0.11$ & $0.23 \pm 0.09$ & \\
\hline & Mean & $0.27 \pm 0.08$ & $0.27 \pm 0.12$ & & \\
\hline & P-Value & \multicolumn{2}{|c|}{1.000} & & 0.898 \\
\hline \multirow{4}{*}{ Bursa } & S1 & $0.05 \pm 0.03$ & $0.05 \pm 0.03$ & $0.05 \pm 0.03$ & \multirow{3}{*}{0.791} \\
\hline & S2 & $0.04 \pm 0.01$ & $0.06 \pm 0.02$ & $0.05 \pm 0.02$ & \\
\hline & Mean & $0.05 \pm 0.02$ & $0.06 \pm 0.03$ & & \\
\hline & P-Value & \multicolumn{2}{|c|}{0.289} & & 0.239 \\
\hline
\end{tabular}

S1: Without vitamin E and Se supplementation, S2: vitamin E supplementation (100 ppm) and Se (1 ppm), R1: Standard ration Lesson and Summers [3], R2: R1 $<5 \%$ metabolic energy and protein requirements

The study results in Table 6 showed that there was no interaction between diet type and vitamin $\mathrm{E}$ and selenium supplementation on percentage of immune organ IPB D-2 chickens. The diet type and vitamin $\mathrm{E}$ and selenium supplementation had no significant effect $(\mathrm{P}>0.05)$ on the percentage of immune organ weights. The weight of the spleen is affected by foreign substances such as toxins, anti-nutritional substances, and diseases that cause the spleen to form lymphoid cells and increase the weight of the spleen. The percentage of spleen weight in this study ranged from $0.35 \%-0.38 \%$. According to Swito, et al. [5], the percentage of spleen weight ranged from $0.33 \%-0.41 \%$ in native chickens was still in the normal range. The percentage of thymus weight was not affected by the treatment. It showed that the ration treatment and the dose of vitamin $\mathrm{E}$ and selenium supplementation were not toxic to the body, so the thymus did not atrophy to disease. The percentage of thymus weight in this study ranged from $0.22 \%-0.32 \%$. According to Harmonis [6], the percentage of average thymus weight ranges from $0.21 \%$ to $-0.28 \%$ in native chickens. Different ration treatments and vitamin E and selenium supplementation were not able to increase the bursa weight. This is due to the growth rate and the regression of the bursa depending on the type, breed, condition of the chicks, and sex hormones [7]. The results of the observations show that the percentage of immune organ weights ranges from $0.05 \%-0.06 \%$. According to Widia, et al. [8], the organ weights weight is around $0.05 \%$ of body weight.

\subsection{Blood profile}

The results of observing the blood profile of IPB D-2 chickens in this study showed that the blood profiles other than erythrocytes and leukocytes were still in the normal range. The 
average number of erythrocytes in this study ranged from 1.94-2.10 million mm-3, so that it was slightly below the normal range. Smith and Mangkoewidjojo [9] stated that normal chicken erythrocytes ranged from 2.0-3.2 million mm-3. While the research conducted by Wahyudi, et al. [10], the average number of erythrocytes ranged from 1.62 to $3.87 \mathrm{x}$ $10^{6} / \mu \mathrm{L}$, which was still in the normal range. The number of erythrocytes will be constant in a relatively normal environment. In this study, the low value of erythrocytes produced can be influenced by the adequacy of nutrition and environmental conditions.

Table 7. Profile of IPB D-2 chicken blood with different diet type and vitamin E and selenium supplementation.

\begin{tabular}{|c|c|c|c|c|}
\hline \multirow{2}{*}{ Parameters } & \multirow{2}{*}{$\begin{array}{l}\text { Supplementation } \\
\text { Vit. E dan Se }\end{array}$} & \multicolumn{2}{|c|}{ Treatment } & \multirow{2}{*}{ Mean } \\
\hline & & R1 & $\mathbf{R 2}$ & \\
\hline \multirow{3}{*}{ Hematocrit } & $\mathrm{S} 1$ & $35.80 \pm 2.93$ & $39.00 \pm 2.76$ & $37.40 \pm 3.26$ \\
\hline & $\mathrm{S} 2$ & $39.60 \pm 2.42$ & $36.00 \pm 0.71$ & $38.00 \pm 2.58$ \\
\hline & Mean & $37.70 \pm 3.29$ & $37.67 \pm 2.58$ & \\
\hline \multirow{3}{*}{ Hemoglobin } & $\mathrm{S} 1$ & $9.16 \pm 1.44$ & $8.60 \pm 0.82$ & $8.91 \pm 1.24$ \\
\hline & $\mathrm{S} 2$ & $9.94 \pm 1.08$ & $7.82 \pm 0.78$ & $8.88 \pm 1.42$ \\
\hline & Mean & $9.55 \pm 1.33$ & $8.17 \pm 0.89$ & \\
\hline \multirow{3}{*}{ Lymphocyte } & $\mathrm{S} 1$ & $57.67 \pm 4.48$ & $58.86 \pm 4.78$ & $58.26 \pm 4.67$ \\
\hline & $\mathrm{S} 2$ & $59.87 \pm 1.47$ & $60.28 \pm 1.62$ & $60.10 \pm 1.57$ \\
\hline & Mean & $58.65 \pm 3.65$ & $59.57 \pm 3.64$ & \\
\hline \multirow{3}{*}{ Heterophil } & $\mathrm{S} 1$ & $34.62 \pm 4.12$ & $34.40 \pm 4.55$ & $34.51 \pm 4.34$ \\
\hline & $\mathrm{S} 2$ & $32.08 \pm 1.46$ & $31.32 \pm 4.49$ & $31.61 \pm 3.51$ \\
\hline & Mean & $33.49 \pm 3.46$ & $32.82 \pm 4.79$ & \\
\hline \multirow{3}{*}{ Erythrocyte } & $\mathrm{S} 1$ & $1.82 \pm 0.43$ & $1.85 \pm 0.27$ & $1.83 \pm 0.37$ \\
\hline & $\mathrm{S} 2$ & $2.06 \pm 0.54$ & $2.14 \pm 0.40$ & $2.10 \pm 0.48$ \\
\hline & Mean & $1.94 \pm 0.50$ & $2.01 \pm 0.38$ & \\
\hline \multirow{3}{*}{ Leucocyte } & $\mathrm{S} 1$ & $\begin{array}{c}31.77 \pm 10.1 \\
1 \\
\end{array}$ & $53.65 \pm 39.37$ & $42.71 \pm 13.36$ \\
\hline & $\mathrm{S} 2$ & $29.40 \pm 7.61$ & $59.58 \pm 38.73$ & $44.40 \pm 16.25$ \\
\hline & Mean & $30.58 \pm 9.03$ & $56.61 \pm 49.03$ & \\
\hline \multirow{3}{*}{ Eosinophile } & $\mathrm{S} 1$ & $2.62 \pm 1.24$ & $3.09 \pm 0.37$ & $2.85 \pm 0.95$ \\
\hline & S2 & $3.38 \pm 0.58$ & $3.81 \pm 0.73$ & $3.57 \pm 0.68$ \\
\hline & Mean & $3.00 \pm 1.04$ & $3.41 \pm 0.66$ & \\
\hline \multirow{3}{*}{ Basophile } & $\mathrm{S} 1$ & $2.27 \pm 0.96$ & $2.36 \pm 0.43$ & $2.32 \pm 0.72$ \\
\hline & $\mathrm{S} 2$ & $3.26 \pm 0.61$ & $1.54 \pm 0.47$ & $2.30 \pm 1.01$ \\
\hline & Mean & $2.76 \pm 0.94$ & $1.95 \pm 0.61$ & \\
\hline \multirow{3}{*}{ Monocyte } & $\mathrm{S} 1$ & $2.06 \pm 0.94$ & $1.29 \pm 0.50$ & $1.68 \pm 0.84$ \\
\hline & $\mathrm{S} 2$ & $1.24 \pm 0.38$ & $1.42 \pm 0.46$ & $1.32 \pm 0.43$ \\
\hline & Mean & $1.65 \pm 0.83$ & $1.35 \pm 0.49$ & \\
\hline \multirow{3}{*}{$\mathrm{H} / \mathrm{L}$} & S1 & $0.61 \pm 0.11$ & $0.53 \pm 0.04$ & $0.57 \pm 0.10$ \\
\hline & $\mathrm{S} 2$ & $0.54 \pm 0.03$ & $0.52 \pm 0.09$ & $0.53 \pm 0.07$ \\
\hline & Mean & $0.58 \pm 0.09$ & $0.52 \pm 0.07$ & \\
\hline
\end{tabular}


S1: Without vitamin E and Se supplementation, S2: vitamin E supplementation (100 ppm) and Se (1 ppm), R1: Standard ration Lesson and Summers [3], R2: R1 $<5 \%$ metabolic energy and protein requirements

The average number of leukocytes of IPB D-2 chickens obtained was 30.58 thousand $m m-3-56.61$ thousand $m m-3$. The results showed that the leukocyte count was higher than the normal range. Smith and Mangkoewidjojo [9] stated that the normal range of leukocyte count in chickens is $16-40$ thousand mm-3. Leukocytes play a role in fighting germs that cause infection and foreign objects that enter the body [11]. Infection will cause an increase in the number of leukocytes due to abnormal physiological conditions that affect the hormonal balance in the chicken body. In this study, the rearing environment had high temperatures and high humidity during the day, causing stress to the chickens. The increased number of leukocytes due to environmental stress will increase the production of corticosteroids and glucocorticoids; this causes a decrease in the chicken's body defence system.

In this study, the $\mathrm{H} / \mathrm{L}$ ratio in IPB $\mathrm{D}-2$ chickens ranged from 0.52 to 0.61 . According to Swenson [12], the normal range of the $\mathrm{H} / \mathrm{L}$ ratio for poultry is $0.45-0.50$. The $\mathrm{H} / \mathrm{L}$ ratio in this study was outside the normal range. According to Gross and Siegeh [13], the heterophile/lymphocyte ratio of $0.2,0.5$, and 0.8 , respectively, is a characteristic of low, optimal, and high-stress levels. Therefore, it can be concluded that the H/L ratio of IPB D-2 chickens obtained from this study has not shown that chickens experience high levels of stress but are still in optimal condition. This result indicates that vitamin $\mathrm{E}$ and selenium can help to improve the immune system in IPB D-2 chickens. This shows that the provision of different rations and vitamin and selenium supplementation can maintain the $\mathrm{H} / \mathrm{L}$ ratio of IPB D-2 chickens in a relatively normal condition. The supplementation of vitamin E $200 \mathrm{mg} \mathrm{kg}-1$ shows the best results in maintaining the health of broilers based on blood profile [14].

\subsection{Percentage of carcass weight}

Table 8. IPB D-2 chicken percentage of carcass weight with different diet type and vitamin E and selenium supplementation.

\begin{tabular}{|c|c|c|c|c|c|}
\hline \multirow{2}{*}{$\begin{array}{l}\text { Parameter } \\
\text { s }\end{array}$} & \multirow{2}{*}{$\begin{array}{l}\text { Supplementatio } \\
\text { n } \\
\text { Vit. E dan Se }\end{array}$} & \multicolumn{2}{|c|}{ Treatment } & \multirow{2}{*}{ Mean } & \multirow{2}{*}{$\begin{array}{l}\text { P- } \\
\text { Value }\end{array}$} \\
\hline & & R1 & $\mathbf{R 2}$ & & \\
\hline \multirow{4}{*}{$\begin{array}{l}\text { Percentage } \\
\text { of carcass } \\
\text { weight }(\%)\end{array}$} & S1 & $63.80 \pm 1.58^{\mathrm{ab}}$ & $60.88 \pm 0.92^{b}$ & $62.50 \pm 1.97$ & \multirow{3}{*}{0.324} \\
\hline & S2 & $62.31 \pm 1.77^{\mathrm{ab}}$ & $64.34 \pm 2.56^{\mathrm{a}}$ & $63.21 \pm 2.38$ & \\
\hline & Mean & $63.05 \pm 1.84$ & $62.61 \pm 2.59$ & & \\
\hline & P-Value & \multicolumn{2}{|c|}{0.657} & & 0.022 \\
\hline
\end{tabular}

S1: Without vitamin E and Se supplementation, S2: vitamin E supplementation (100 ppm) and Se (1 ppm), R1: Standard ration Lesson and Summers [3], R2: R1 $<5 \%$ metabolic energy and protein requirements

The study results in Table 8 showed that there was significant interaction $(\mathrm{P}<0.05)$ between diet type and vitamin $\mathrm{E}$ and selenium supplementation on the percentage of chicken carcasses of IPB D-2. The highest carcass percentage was produced by R2S2 treatment. It was found that higher consumption and body weight gain in the R2S2 treatment than other 
treatments before the chicken was slaughtered. Pahlepi, et al. [15] stated that the higher the feed consumption, the higher the body weight gain produced so that the carcass weight obtained was also high and vice versa. The higher carcass percentage in the R2S2 treatment also indicated that vitamin $\mathrm{E}$ and selenium as antioxidants could reduce stress and maintain the performance of IPB D-2 chickens even though the ration formula was reduced from the standard requirement.

\subsection{Egg production}

Table 9. IPB D-2 chicken egg production in the player period with different diet type and vitamin E and selenium supplementation.

\begin{tabular}{|l|l|c|c|c|}
\hline \multirow{2}{*}{ Parameters } & \multirow{2}{*}{$\begin{array}{l}\text { Supplementation } \\
\text { Vit. E dan Se }\end{array}$} & \multicolumn{2}{|c|}{ Treatment } & \multirow{2}{*}{ Mean } \\
\cline { 2 - 4 } & S1 & R1 & R2 & \\
\hline \multirow{3}{*}{$\begin{array}{l}\text { Hen Day } \\
\text { Production pre- } \\
\text { layer }\end{array}$} & S2 & $0.40 \pm 0.80$ & $0.00 \pm 0.00$ & $0.20 \pm 0.60$ \\
\cline { 2 - 5 } & Mean & $0.50 \pm 0.87$ & $0.00 \pm 0.00$ & $0.22 \pm 0.63$ \\
\hline \multirow{3}{*}{$\begin{array}{l}\text { Hen Day } \\
\text { Production layer }\end{array}$} & S1 & $0.44 \pm 0.83$ & $0.00 \pm 0.00$ & \\
\cline { 2 - 5 } & S2 & $0.80 \pm 0.60$ & $0.00 \pm 0.00$ & $0.40 \pm 1.20$ \\
\cline { 2 - 5 } & Mean & $0.00 \pm 0.00$ & $0.80 \pm 1.60$ & $0.44 \pm 1.26$ \\
\hline
\end{tabular}

S1: Without vitamin E and Se supplementation, S2: vitamin E supplementation (100 ppm) and Se (1 ppm), R1: Standard ration Lesson and Summers [3], R2: R1 <5\% metabolic energy and protein requirements

The results in the table show that different ration treatments and vitamin $\mathrm{E}$ and selenium supplementation had no significant effect $(\mathrm{P}>0.05)$ on Hen Day Production $(\%)$. The average Hen Day Production obtained during this study ranged from $0.00 \%-0.44 \%$. According to Brickman [16], the factors affecting egg production are the seeds used, age, housing, lighting, feed, and environmental temperature. The production period also affects egg production [17]. In this study, IPB D-2 chickens aged 17-19 weeks in the player period and 19-21 weeks in the layer period. So that the resulting egg production is not optimal because the age is not ready to lay eggs. According to Habiburahman, et al. [18] the age of 24 weeks was the age of laying eggs in IPB D-1 G7 chickens.

\section{Conclusion}

The diet type with a 5\% reduce from the standard with supplementation vitamin E (100 ppm) dan selenium (1ppm) showed the best result for IPB D-2 chickens performance, maintenance of immune organ and blood profile. 


\section{References}

1. C. Sumantri, S. Darwati, Proceedings of the National Livestock Industry Seminar, 1, 29-30 (2017)

2. V. Shinde's, K. Dhalwal, A. R. Paradkar, K. R. Mahadik, Pharmacologyonline, 1, 252261 (2007)

3. S. Lesson, J. D. Summers, Commercial Poultry Nutrition, 3 (2005)

4. M. Rasyaf, Beternak ayam kampung. (Panebar Swadaya, Jakarta, Indonesia, 2005)

5. Swito, D. Sudrajat, R. Handarini, Journal of Animal Husbandry Nusantara, 1, 25-32 (2015)

6. M. Harmonis (2019)

7. B. Glick, Sturkie's Avian Physiology, 5, 658-659 (2000)

8. E. Widia, E. Widiastuti E, A. S. Teysar, Prosiding STAP FAPET UNSOED, 5, 297301 (2017)

9. J. B. Smith, S. Mangkoewidjojo, Maintenance, Breeding, and Use of Experimental Animals in the Tropics (1988)

10. Wahyudi, A. Indi, M. A. Pagala, Halu Oleo Animal Husbandry Scientific Journal, 3, 137-142 (2021)

11. Isroli, S. Susanti, E. Widiastuti, T. Yudiarti, Sugiharto, Prosiding Seminar Nasional Kebangkitan Peternakan, 548-557 (2009)

12. M. J. Swenson, Duke's Physiology of Domestic Animals, 10 (1984)

13. W. B. Gross, H. S. Siegel, Avian Dis, 27, 972-979 (1983)

14. F. Meidita, Sumiati, S. Tuti, AIP Conference Proceedings, 2296 (2020)

15. R. Pahlepi, H. Hapid, A. Indi, JITRO, 2, 1-7 (2015)

16. W. L. Brickman, Poultry Production in Tropical Areas, 11 (1989)

17. S. Baktiningsih, S. Mugiyono, D. M. Saleh, JEEP, 1, 993-1000 (2013)

18. R. Habibburahman, S. Darwati, C. Sumantri, Rukmiasih, Journal of Animal Production Science and Technology, 8, 97-101 (2020) 